\title{
MIŠLJENJA STUDENATA PRIMARNOG OBRAZOVANJA O OBILJEŽJIMA PROFESIJE
}

\author{
Petra Kuntin \\ Učiteljski fakultet, Sveučilište u Zagrebu, \\ Hrvatska \\ petra.kuntin@ufzg.hr
}

Primljeno: 20. 11. 2020.

\begin{abstract}
Cilj istraživanja je utvrditi mišljenje studenata primarnog obrazovanja o obilježjima profesije. Nezavisne varijable istraživanja su trenutačna godina studija, vrsta prethodno završene srednje škole te modul/smjer koji studenti pohađaju. Istraživanje je provedeno anketnim upitnikom u akademskoj godini 2019./2020., a uzorak čine studenti/ce prve i pete godine Učiteljskog fakulteta Sveučilišta u Zagrebu. Rezultati pokazuju da studenti primarnog obrazovanja prepoznaju obilježja profesije te postojanje statistički značajne razlike s obzirom na godinu studija $i$ vrstu prethodno završene srednje škole.
\end{abstract}

Ključne riječi: primarno obrazovanje, profesija, studenti, učitelj

\section{Uvod}

Definiranje profesije temelj je za razumijevanje opsega i dubine posla profesionalaca. Etimološki gledano, pojmovi profesija i profesionalac dolaze od latinske riječi professio i podrazumijevaju djelatnost za koju tko ima određenu spremu i kojom zarađuje za život, odnosno osobu koja se bavi nekim poslom kao stalnom profesijom, koja obavlja svoj posao savjesno, vješto i temeljito (Anić i Goldstein, 2005, 469). Zanimljivo je istaknuti da rječnici stranih riječi profesiju predstavljaju kao sinonim zanimanja te je definiraju kao djelatnost za koju tko ima određenu spremu i kojom zarađuje za život; služba, struka, zanimanje, zvanje (Anić i Goldstein, 2005, 469), odnosno kao stalno zanimanje; vrstu djelatnosti, vrstu zanimanja koja služi kao izvor egzistencije, 
odnosno zvanje, služba; struka, stalež (Klaić, 2001, 1093). Međutim, pregledom literature dolazi se do zaključka da se profesija i zanimanje ipak ne mogu shvaćati sinonimima. To pokazuju i istraživanja profesije koja su sociolozi započeli 30-ih godina 20. stoljeća pokušavajući definirati obilježja kojima se profesija razlikuje od ostalih zanimanja. Kao obilježja najčešće su se navodila: vještine utemeljene na apstraktnom znanju, osiguravanje izobrazbe i edukacije koja je najčešće povezana sa sveučilištem, certifikat temeljen na provjeri sposobnosti, formalna organizacija, pridržavanje kodeksa ponašanja te altruistička služba. Takav način shvaćanja profesije nazvan je Model osobina profesije (Runte, 1995). Daljnja nastojanja definiranja profesije nastavljaju se 50 -ih i 60-ih godina 20. stoljeća kada nastaje Strukturalno-funkcionalni model shvaćanja profesije. Strukturalno-funkcionalni model nastavlja se na Model osobina profesije međusobno povezujući različita obilježja. Primjerice, smatrano je da sveučilišno obrazovanje i certifikat temeljen na provjeri sposobnosti logički proizlaze iz svojstva vještine utemeljene na apstraktnom znanju. Tadašnje shvaćanje pojma profesija podrazumijevalo je da svaka profesija posjeduje široki spektar obilježja kojima se razlikuje od druge profesije, odnosno posjedovanje visokog stupnja znanja i iskustva uz ostala obilježja poput etičkog kodeksa, altruizma, racionalnosti i licence (Runte, 1995; Saks, 2012, 2). Iako i u 21. stoljeću shvaćanje profesije svoje temelje pronalazi u dva predstavljena modela, nije postignuta njezina jedinstvena definicija, no sličnosti među postojećim definicijama su nepobitne. Tako Cobbold $(2015,126)$ smatra da profesiju obilježava snažna tehnička kultura sa specijaliziranim skupom znanja koje je dobiveno tijekom duljeg perioda izobrazbe. Ingersoll i Perda $(2008,107)$ navode da profesionalci, u odnosu na laike, imaju visoki stupanj kontrole nad svojim radnim okruženjem, visoki prestiž i relativno visoku naknadu te da je bit profesije napredna izobrazba. Isti autori, vođeni sociološkim profesionalnim modelom, iznose niz indikatora kojima se procjenjuje stupanj profesionalizacije naglašavajući da to nisu jedini indikatori za procjenu stupnja profesionalizacije, ali imaju široku uporabu: licenciranje, uvođenje u profesiju i mentorski programi, podrška, mogućnosti i sudjelovanje u profesionalnom razvoju, specijalizacija, autonomnost u donošenju odluka, visina naknade te prestiž i status u društvu. Petričević $(2011,14)$ u svom radu ističe da bi profesionalno bavljenje određenom djelatnošću trebalo podrazumijeva- 
ti bavljenje tom istom djelatnosti kao stalnim zanimanjem te ostvarivanje odgovarajuće novčane naknade za pružene usluge. Također, Petričević navodi definicije profesije nekoliko različitih autora (Antić, 2000; Mušanović, 2001; Rajković et al., 1993, u: Petričević, 2011, 14) prema kojima je profesija visoko složeno zanimanje koje ima monopol nad nekim kompleksnim dijelom znanja i praktičnih vještina za koje je potrebno visoko obrazovanje; djelatnost koju pojedinac obavlja i za koju ima kvalifikaciju; osposobljenost (stručnost), i područje djelatnosti u kojem je netko prema društvenoj podjeli rada raspoređen (institucionalizirano zanimanje - poziv), i radne zadatke koje netko stalno obavlja u sklopu određenog područja rada; visokostručna radna djelatnost koja se izvodi na temelju: primjene teorijskog znanja struke i znanstvene metodologije struke, društvene i kolegijalne kontrole, prava na stručnu autonomiju i monopol na ekspertizu, trajnijeg obavljanja rada, stručnoga autoriteta, i razvoja profesionalne subkulture. Turner i Hodge $(1970,26)$ navode četiri stupnja razvijene profesije. Prvi stupanj odnosi se na razvijenost osnovnih teorija i tehnika koje čine sistematski zaokruženu cjelinu, drugi stupanj na monopol na ekspertizu, treći stupanj na prepoznatljivost $u$ javnosti i četvrti stupanj na organiziranost.

Peti stupanj, razvijenost profesionalne etike, pridodala je Šporer $(1990,35)$. Profesija se temelji i na obilježjima koja

»... predstavljaju stalno zanimanje, zahtijevaju posebno prethodno obrazovanje i kasnije usavršavanje, pripadnici profesije udružuju se u strukovna udruženja na nacionalnoj razini, mogućnost obavljanja profesionalne djelatnosti regulirana je propisom, a profesionalni je rad podvrgnut profesionalnoj etici i kontroli kolega.« (Musa i Džinić, 2012, 1)

Musa i Džinić $(2012,10)$ također navode da je stjecanje specijaliziranog znanja i vještina u za to posebno formiranim ustanovama (sveučilišta, škole, organizacije za stručno usavršavanje) jedno od ključnih obilježja profesije. Domović $(2011,15)$ analizom različitih definicija profesije iznosi tipična obilježja profesije: društveno vrijedan posao bitan za razvoj ključnih socijalnih i ljudskih vrijednosti, posjedovanje visoke razine specifičnih znanja i vještina, primjena znanja i vještina za rješavanje različitih problemskih situacija, dug period školovanja $i$ usvajanja praktičnih vještina, rukovođenje etičkim kodeksom, sloboda u donošenju vlastitih procjena koje su u skladu s odgovarajućom praksom, posjedovanje visokog stupnja kontrole nad izvršavanjem svoje 
djelatnosti te visokog stupnja autonomije u odnosu na državu, dugoročna predanost profesiji članova profesije, cjeloživotno usavršavanje znanja i vještina, visoki status i plaća. Victoria (2018) iznosi svoje viđenje profesije prema kojem profesionalac razvija i posjeduje korpus znanja koji mu daje profesionalnu moć koja ga odvaja od laika. Takva moć pojačana je diferenciranim pristupom resursima specifičnim za pojedinu profesiju. Prema članku 5. Zakona o reguliranim profesijama $i$ priznavanju inozemnih stručnih kvalifikacija (NN 82/2015) regulirana profesija definira se kao:

»... profesionalna djelatnost ili skupina profesionalnih djelatnosti kod kojih je pristup, obavljanje ili jedan od načina obavljanja na temelju zakonskih ili drugih pravnih akata, izravno ili neizravno uvjetovan posjedovanjem određenih stručnih kvalifikacija te profesionalna djelatnost ili skupina profesionalnih djelatnosti kojima se bave članovi strukovnih organizacija s profesionalnim nazivom.«

Pregledom literature dolazi se do zaključka kako nema univerzalne definicije profesije i profesionalaca, već ih autori i akti različito definiraju. Iz navedenog se može zaključiti da se kao najčešće definirajuće komponente profesije izdvajaju: dulji period izobrazbe, odnosno sveučilišno obrazovanje koje rezultira specifičnim vještinama i znanjima svojstvenima samo za određenu profesiju, djelovanje u skladu s etičkim kodeksom, kontinuirano profesionalno usavršavanje, autonomija, prestiž, sustav licenciranja, visoka naknada te postojanje komora, odnosno profesionalnih udruženja.

Prema bazi podataka Agencije za znanost i visoko obrazovanje, u Hrvatskoj postoje 53 grupe reguliranih profesija. Odnosno, cjeloviti popis uključuje 188 reguliranih profesija. Jedna od njih je i učitelj $u$ osnovnoj školi koja pripada grupi profesija pod nazivom Odgoj $i$ obrazovanje u školskoj ustanovi. Kako ne postoji jednoznačna definicija profesije, tako ne postoji niti jednoznačna definicija učiteljske profesije. Ingersoll i Perda $(2008,106)$ navode da od početka 20. stoljeća učitelji i nastavnici smatraju da je učiteljstvo izrazito kompleksan posao koji zahtijeva specijalizirano znanje i vještine. Hotaman (2010, 1419) pod umjetničkim i znanstvenim obilježjima učiteljske profesije ključnima za postizanje ciljeva odgoja i obrazovanja podrazumijeva znanje iz predmeta, učiteljske vještine te osobine ličnosti. Isti autor navodi da se učiteljska profesija temelji na specijalizaciji određenog područja, vje- 
štinama poučavanja, didaktici i određenim osobnim obilježjima koje profesija zahtjeva. Hacioglu (1997) učiteljsku profesiju opisuje kao profesionalno udruženje obrazovnog sektora koje posjeduje socijalnu, kulturalnu, ekonomičnu, znanstvenu i tehnološku dimenziju (navedeno u Hotaman, 2010, 1416). U publikaciji koju je izdao Department of Education and Skills (2001) navode se zahtjevi novog doba i novo razumijevanje profesije te se iznose obilježja novog profesionalizma učitelja: visoki standardi na ključnim razinama profesije (uključujući ulaz u profesiju i vodstvo) koje regulira jako tijelo profesije, korpus znanja o tome što najbolje funkcionira i zašto (s redovitim prilikama za profesionalno usavršavanje i razvoj), učinkovita organizacija i vodstvo dodatnog osoblja, učinkovita uporaba informacijsko-komunikacijske tehnologije, poticaji i nagrade za izvrsnost te neiscrpan fokus na ono što je u najboljem interesu za učenike i roditelje poduprt jasnim i učinkovitim dogovorima vezanima za odgovornost te za mjerenje izvedbe i ishoda. OECD $(2016 b, 32)$ učiteljski profesionalizam povezuje s posjedovanjem snažnog korpusa znanja, autonomije u donošenju odluka te snažnog povezivanja s kolegama, a navode da je potrebno posjedovanje vještina i motivacije. Komponente kojima se opisuje učiteljska profesija proizlaze iz prethodno navedenih komponenti profesija. Među inima se ističu: znanje i vještine iz specifičnih područja (didaktika, metodika), kontinuirani profesionalni razvoj i usavršavanje te autonomija u donošenju odluka. Zanimljivo je istaknuti da se kao specifično obilježje učiteljske profesije u navedenim definicijama ne navodi postojanje profesionalnog udruženja (komore), etičkog kodeksa ili sustava licenciranja što se iznova ponavlja u općenitim definicijama profesije. U slučaju Republike Hrvatske nije formirana učiteljska komora i etički kodeks za učitelje dok je sustav licenciranja definiran Zakonom o odgoju i obrazovanju u osnovnoj i srednjoj školi (NN, 87/08).

Istraživanja doživljaja učiteljstva kod učitelja kao profesije dolaze do različitih nalaza. Tako istraživanje provedeno 2015. godine u Gani pokazuje da se učitelji smatraju profesionalcima, ali učiteljstvo ne smatraju punopravnom profesijom (Cobbold, 2015, 129). Neka istraživanja pokazuju da doživljaj učiteljske profesije proizlazi iz osobnih iskustava učitelja (Bergmark et al., 2018, 8) što je značajan nalaz jer profesionalna uvjerenja čine jezgru profesionalnog identiteta učitelja (Domović i Vizek Vidović, 2013, 493). Istraživanje koje su proveli Hargreaves et 
al. $(2007,1)$ pokazuje da učitelji učiteljstvo percipiraju kao manje nagrađenu, ali više kontroliranu i reguliranu profesiju u usporedbi s profesijama višeg statusa (poput liječničke i odvjetničke profesije). Zanimljivo je istaknuti rezultate TALIS istraživanja provedenog 2018. godine prema kojima je više od $70 \%$ hrvatskih učitelja zadovoljno svojom profesijom te smatraju da učiteljska profesija ima više prednosti nego nedostataka (Markočić Dekanić et al., 2019, 151). Istraživanje koje je proveo Demir $(2016,307)$ pokazuje da studenti učiteljskih studija uglavnom imaju pozitivno mišljenje o učiteljskoj profesiji. Zanimljivi su i rezultati istraživanja koje su proveli Fokkens-Bruinsma i Canrinus $(2014,72)$, a prema kojem su studenti učiteljskih fakulteta neodlučni kada je riječ o tome doživljavaju li se učitelji profesionalcima, odnosno ne mogu procijeniti doživljava li društvo učitelje profesionalcima ili ne. Kao što je već navedeno, učiteljstvo u Republici Hrvatskoj definirano je kao regulirana profesija Zakonom o reguliranim profesijama $i$ priznavanju inozemnih stručnih kvalifikacija (NN 82/2015), međutim ne nailazi se na istraživanje koje pokazuje kako studenti učiteljskih studija doživljavaju učiteljsku profesiju, odnosno kako doživljavaju i prepoznaju li elemente profesije u generalnom smislu. Stoga, u ovom radu bit će prikazano mišljenje studenata primarnog obrazovanja o obilježjima profesije. Time će se utvrditi na koji način studenti primarnog obrazovanja shvaćaju profesiju što daje podlogu za daljnja istraživanja kojima bi se moglo ispitati u kojoj mjeri se učitelji identificiraju s učiteljskom profesijom i doživljavaju li sebe profesionalcima.

\section{Metodologija istraživanja}

\subsection{Cilj i zadatci istraživanja}

Cilj istraživanja je utvrditi mišljenje studenata primarnog obrazovanja o obilježjima profesije.

Postavljeni su sljedeći zadatci istraživanja:

1. Utvrditi postoji li statistički značajna razlika u mišljenjima studenata primarnog obrazovanja o obilježjima profesije s obzirom na trenutačnu godinu studija. 
2. Utvrditi postoji li statistički značajna razlika u mišljenjima studenata primarnog obrazovanja o obilježjima profesije s obzirom na vrstu prethodno završene srednje škole.

3. Utvrditi postoji li statistički značajna razlika u mišljenjima studenata primarnog obrazovanja o obilježjima profesije s obzirom na smjer.

\subsection{Hipoteze istraživanja}

Navedene hipoteze formirane su u afirmativnom ili nultom obliku:

1. Postoji statistički značajna razlika u mišljenjima studenata primarnog obrazovanja o obilježjima profesije s obzirom na trenutačnu godinu studija.

2. Postoji statistički značajna razlika u mišljenjima studenata primarnog obrazovanja o obilježjima profesije s obzirom na vrstu prethodno završene srednje škole.

3. Ne postoji statistički značajna razlika u mišljenjima studenata primarnog obrazovanja o obilježjima profesije s obzirom na smjer.

Pretpostavka očekivane statistički značajne razlike u mišljenjima budućih učitelja primarnog obrazovanja o obilježjima profesije s obzirom na trenutačnu godinu studija objašnjava se razlikom u kolegijima koje studenti pohađaju tijekom prve, odnosne pete godine studiranja. Na prvoj godini studija veća je zastupljenost općeobrazovnih predmeta: Geografija, Matematika, Hrvatska gramatika, Hrvatski pravopis, Hrvatska povijest, Prirodoslovlje i Kineziološka kultura (Učiteljski fakultet Sveučilišta u Zagrebu, 2019, 17, 39). Tijekom preostale četiri godine studiranja, studenti polaze kolegije čiji ih sadržaj izravno dovodi u vezu s učiteljskom profesijom. Kolegijima poput: Motivacija i socijalni odnosi u razredu, Teorije nastave i obrazovanja, Povijest pedagogije i školstva, Nastavni kurikulum, Ocjenjivanje u primarnom obrazovanju, Sociologija obrazovanja, Inkluzivna pedagogija, Školski sustavi, Školski propisi i dokumentacija te metodike svih predmeta razredne nastave (Učiteljski fakultet Sveučilišta u Zagrebu, 2019, 17-18, 39-40) studenti stječu i produbljuju znanje o vlastitoj profesiji te se s njome, u većoj ili manjoj mjeri, počinju identificirati.

Pretpostavka očekivane statistički značajne razlike u mišljenjima budućih učitelja primarnog obrazovanja o obilježjima profesije $\mathrm{s}$ 
obzirom na vrstu prethodno završene srednje škole (gimnazija, strukovna škola) objašnjava se razlikom u programima navedenih škola. Gimnazijski program tijekom sve četiri godine zastupljen je općeobrazovnim predmetima. S druge strane, program strukovnih škola zasićen je strukovno-specifičnim predmetima. Primjerice, prve dvije godine petogodišnjeg programa srednje škole za medicinske sestre uključuju općeobrazovne predmete dok se preostale tri godine isključivo odnose na strukovno-specifične predmete (Anatomija i fiziologija, Zdravstvena njega - opća, Zdravstvena njega bolesnog djeteta i adolescenta, Hitni medicinski postupci i dr.). Pretpostavlja se da bi zbog toga studenti koji su prethodno pohađali srednju strukovnu školu mogli biti više upoznati s obilježjima profesije.

Pretpostavka neočekivane statistički značajne razlike u mišljenjima budućih učitelja primarnog obrazovanja o obilježjima profesije $\mathrm{s}$ obzirom na smjer objašnjava se nepostojanjem razlike u kolegijima kojima su studenti izloženi, a koji se odnose na učiteljsku profesiju. Svi studenti do završetka studija moraju odslušati i položiti kolegije Motivacija i socijalni odnosi u razredu, Teorije nastave i obrazovanja, Nastavni kurikulum, Inkluzivna pedagogija te metodike svih predmeta razredne nastave. Pretpostavlja se da će se navedenim kolegijima postići određena osjetljivost studenata za učiteljsku profesiju neovisno o smjeru koji pohađaju. Posljedično razvijenoj osjetljivosti za učiteljsku profesiju, pretpostavlja se da bi studenti mogli prepoznati obilježja profesije na općenitoj razini.

\subsection{Uzorak istraživanja}

Istraživanje mišljenja budućih učitelja primarnog obrazovanja o obilježjima profesije provedeno je na prigodnom uzorku budućih učitelja primarnog obrazovanja prve i pete godine središnjice Učiteljskog fakulteta Sveučilišta u Zagrebu te odsjeka u Petrinji ( $\mathrm{N}=244)$. Uzorak čini ukupno 121 (49,6\%) student prve i $123(50,4 \%)$ studenta pete godine. Od ukupnog broja ispitanika njih $196(80,3$ \%) završilo je gimnaziju, a 47 (19,3\%) strukovnu školu. Nadalje, njih 87 (35,7\%) pohađa smjer 835 (Engleski jezik, Njemački jezik), a njih 157 (64,3\%) smjer 903 (Moduli). Smjer 835 odnosi se na integrirani učiteljski studij smjer njemački/engleski jezik kojim se studenti kvalificiraju za radno mjesto 
učitelja razredne nastave i učitelja njemačkog ili engleskog jezika od prvog do osmog razreda osnovne škole dok se smjer 903 odnosi na integrirani učiteljski studij s modulima (Hrvatski jezik, Informatika, Likovna kultura, Odgojne znanosti) kojim se studenti kvalificiraju za radno mjesto učitelja razredne nastave i učitelja hrvatskog jezika/informatike/ likovne kulture od petog do osmog razreda. Završetkom modula Odgojne znanosti studenti su kvalificirani samo za radno mjesto učitelja razredne nastave. Sudjelovanje u istraživanju bilo je dobrovoljno te je sudionicima zajamčena anonimnost time što se nije tražilo upisivanje osobnih podataka (npr. ime, prezime, adresa elektroničke pošte) na anketni upitnik.

\subsection{Postupak, metoda $i$ instrument istraživanja}

Istraživanje je provedeno anketiranjem anketnim upitnikom u akademskoj godini 2019./2020. Kao instrument istraživanja korišten je prilagođeni anketni upitnik preuzet od Cobbold (2015) uz dopuštenje autora. Upitnik se sastoji od dvaju dijelova. Prvi dio odnosi se na sociodemografske podatke ispitanika koji uključuju informacije o trenutačnoj godini studija (prva ili peta godina studija), prethodno završenoj srednjoj školi (gimnazija ili strukovna srednja škola) te smjeru (835 ili 903) koji ispitanici pohađaju. Drugi dio upitnika sastoji se od 10 čestica koje se procjenjuju na skali Likertovog tipa od pet stupnjeva (od $1-\mathrm{u}$ potpunosti se ne slažem, do 5 - u potpunosti se slažem). Čestice upitnika čini deset tvrdnji kojima se izražavaju obilježja profesije. Tvrdnje upitnika u izvornom istraživanju procjenjivane su dvama stupnjevima (odnosi se na mene ili ne odnosi se na mene) dok su u prilagođenom upitniku proširene na pet stupnjeva zbog boljeg diferenciranja ispitanika.

\subsection{Vrsta nacrta istraživanja}

Prema podjeli koju je napravio Mejovšek $(2008,20)$ korišten je diferencijalni neeksperimentalni nacrt jer je u pitanju utvrđivanje razlika određenih subskupina (vrsta završene srednje škole, godina studija i smjer) na određenoj zavisnoj varijabli (mišljenje o obilježjima profesije i profesionalaca). Za analizu podataka korišten je t-test za dva nezavisna uzorka jer se radi o dvama nezavisnim uzorcima (studenti prve ili 
studenti pete godine; studenti smjera 853 ili smjera 903; studenti s prethodno završenom strukovnom školom ili gimnazijom) koji su testirani samo jednom.

\section{Rezultati}

Prije računanja obrade podataka u svrhu odgovora na postavljene zadatke istraživanja izračunata je deskriptivna statistika (Tablica 1) te normaliteti distribucija zavisnih varijabli u istraživanju.

Tablica 1. Deskriptivna statistika i normaliteti distribucija

\begin{tabular}{|c|c|c|c|c|c|c|c|c|c|}
\hline Zavisne varijable & $\mathbf{M}$ & C & D & sd & 志 & : & $\begin{array}{l}\widehat{3} \\
\sqrt[3]{1}\end{array}$ & $\frac{a}{\infty}$ & 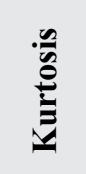 \\
\hline $\begin{array}{l}\text { Profesija pruža } \\
\text { jedinstvenu, odre- } \\
\text { đenu i esencijalnu } \\
\text { uslugu koju mogu } \\
\text { pružiti jedino } \\
\text { osobe s potrebnom } \\
\text { kvalifikacijom za } \\
\text { određenu profe- } \\
\text { siju. }\end{array}$ & 4.5 & 5.0 & 5.0 & 0.65 & 2 & 5 & $\begin{array}{c}0.34 * * \\
(0.01)\end{array}$ & -1.00 & 0.69 \\
\hline $\begin{array}{l}\text { Profesija se } \\
\text { uglavnom oslanja } \\
\text { na intelektualne } \\
\text { vještine i tehnike } \\
\text { kako bi se pruži- } \\
\text { la odgovarajuća } \\
\text { usluga. }\end{array}$ & 4.1 & 4.0 & 4.0 & 0.81 & 2 & 5 & $\begin{array}{c}0.25^{* *} \\
(0.01)\end{array}$ & -0.56 & -0.22 \\
\hline $\begin{array}{l}\text { Profesija podrazu- } \\
\text { mijeva dugi period } \\
\text { specijalizirane } \\
\text { izobrazbe. }\end{array}$ & 4.5 & 5.0 & 5.0 & 0.65 & 2 & 5 & $\begin{array}{c}0.36^{* *} \\
(0.01)\end{array}$ & -1.02 & 0.31 \\
\hline
\end{tabular}




\begin{tabular}{|c|c|c|c|c|c|c|c|c|c|}
\hline $\begin{array}{l}\text { Individualni pri- } \\
\text { padnici profesije } \\
\text { te profesija kao } \\
\text { skupina posjeduju } \\
\text { značajan stupanj } \\
\text { autonomije i moći } \\
\text { odlučivanja. }\end{array}$ & 4.0 & 4.0 & 4.0 & 0.81 & 2 & 5 & $\begin{array}{l}0.24 * * \\
(0.01)\end{array}$ & -0.45 & -0.47 \\
\hline $\begin{array}{l}\text { Profesija obvezuje } \\
\text { svoje pripadnike } \\
\text { da prihvate osobnu } \\
\text { odgovornost za } \\
\text { svoja djela i odlu- } \\
\text { ke i općenito svoju } \\
\text { izvedbu. }\end{array}$ & 4.6 & 5.0 & 5.0 & 0.60 & 2 & 5 & $\begin{array}{l}0.39^{* *} \\
(0.01)\end{array}$ & -1.34 & 1.90 \\
\hline $\begin{array}{l}\text { Profesija više } \\
\text { stavlja naglasak } \\
\text { na usluge koje } \\
\text { pružaju njezini } \\
\text { pripadnici nego na } \\
\text { njihove financijske } \\
\text { nagrade. }\end{array}$ & 4.3 & 4.0 & 5.0 & 0.86 & 1 & 5 & $\begin{array}{l}0.28^{* *} \\
(0.01)\end{array}$ & -1.45 & 3.09 \\
\hline $\begin{array}{l}\text { Profesija je sa- } \\
\text { moregulirajuća; } \\
\text { odgovorna je za } \\
\text { uređenje unutar- } \\
\text { nje strukture i za } \\
\text { postavljanje stan- } \\
\text { darda za primanje } \\
\text { i isključivanje iz } \\
\text { profesije. }\end{array}$ & 3.9 & 4.0 & 4.0 & 0.99 & 1 & 5 & $\begin{array}{l}0.24 * * \\
(0.01)\end{array}$ & -1.13 & 2.42 \\
\hline $\begin{array}{l}\text { Profesija ima } \\
\text { kodeks ponašanja } \\
\text { koji postavlja } \\
\text { prihvatljive stan- } \\
\text { darde ponašanja za } \\
\text { svoje pripadnike } \\
\text { profesije. }\end{array}$ & 4.4 & 5.0 & 5.0 & 0.70 & 1 & 5 & $\begin{array}{c}0.33^{* *} \\
(0.01)\end{array}$ & -1.37 & 2.63 \\
\hline
\end{tabular}




\begin{tabular}{|l|l|l|l|l|l|l|l|l|l|l|}
$\begin{array}{l}\text { Pripadnici pro- } \\
\text { fesije posjeduju } \\
\text { suvremeno znanje } \\
\text { vezano za specifič- } \\
\text { no područje. }\end{array}$ & 4.2 & 4.0 & 4.0 & 0.78 & 1 & 5 & $\begin{array}{c}0.25^{* *} \\
(0.01)\end{array}$ & -1.06 & 1.63 \\
\hline $\begin{array}{l}\text { Svi pripadnici } \\
\text { profesije imaju } \\
\text { odgovornost uklju- } \\
\text { citi se u aktivnosti } \\
\text { svoje profesional- } \\
\text { ne organizacije. }\end{array}$ & 4.4 & 5.0 & 5.0 & 0.74 & 2 & 5 & $\begin{array}{l}0.31^{* *} \\
(0.01)\end{array}$ & -0.97 & 0.34 \\
\hline
\end{tabular}

Legenda: $\mathrm{M}$ - aritmetička sredina; $\mathrm{C}$ - centralna vrijednost; D - dominantna vrijednost; sd - standardna devijacija, min - najmanji rezultat; max - najveći rezultat, KS - vrijednost Kolmogorov Smirnov testa pri testiranju značajnosti distribucije; ** - značajno uz $5 \%$ rizika $(\mathrm{p}<0.05)$; * - značajno uz $1 \%$ rizika $(\mathrm{p}<0.01) ; \mathrm{p}$ - vjerojatnost pogreške; skewness - asimetričnost distribucije; kurtosis - spljoštenost distribucije

Rezultati u gornjoj tablici donose informaciju da se sve distribucije rezultata statistički značajno razlikuju od normalne raspodjele. Kako rezultati vezani uz asimetričnost (skewness) i spljoštenost (kurtosis) distribucije pokazuju da niti kod jedne distribucije rezultata nema ozbiljne narušenosti u izgledu distribucije što je prema Kline (2010, 60) kada vrijednosti asimetričnosti nikada ne prelaze 3 niti vrijednosti spljoštenosti ne prelaze 10 , u daljnjoj obradi podataka koristila se parametrijska statistika.

Dodatno, temeljem gornje tablice može se uočiti da se sudionici istraživanja najviše slažu s tvrdnjama »Profesija obvezuje svoje pripadnike da prihvate osobnu odgovornost za svoja djela i odluke i općenito svoju izvedbu « $(\mathrm{M}=4.6 ; \mathrm{sd}=0.60)$, »Profesija pruža jedinstvenu, određenu i esencijalnu uslugu koju mogu pružiti jedino osobe s potrebnom kvalifikacijom za određenu profesiju« $(\mathrm{M}=4.5$; sd = 0.65) i »Profesija podrazumijeva dugi period specijalizirane izobrazbe« $(\mathrm{M}=4.5$; $\mathrm{sd}=0.65)$. Sve ove tvrdnje imaju vrijednosti aritmetičke sredine 4.5 ili više što znači da se nalaze u kategoriji potpunog slaganja. Najmanje slaganje uočava se za tvrdnju »Profesija je samoregulirajuća; odgovorna je za uređenje unutarnje strukture i za postavljanje standarda za primanje i isključivanje iz profesije « $(\mathrm{M}=3.9 ; \mathrm{sd}=0.99)$ te se ova tvrdnja nalazi u kategoriji slažem se kao i sve ostale tvrdnje. 
Da bi se odgovorilo na prvi zadatak istraživanja, odnosno provjerilo postoji li statistički značajna razlika u mišljenjima budućih učitelja primarnog obrazovanja o obilježjima profesije s obzirom na trenutačnu godinu studija, provedeni su t-testovi za nezavisne uzorke za sve zavisne varijable (Tablica 2).

Tablica 2. Rezultati t-testa pri testiranju razlike u mišljenjima budućih učitelja primarnog obrazovanja o obilježjima profesije s obzirom na trenutačnu godinu studija $(\mathrm{df}=242)$

\begin{tabular}{|c|c|c|c|c|}
\hline Zavisne varijable & t-test & $\mathbf{p}$ & M(sd) 1.g. & M(sd) 5.g. \\
\hline $\begin{array}{l}\text { Profesija pruža jedinstvenu, } \\
\text { određenu i esencijalnu uslugu } \\
\text { koju mogu pružiti jedino } \\
\text { osobe s potrebnom kvalifika- } \\
\text { cijom za određenu profesiju. }\end{array}$ & $-1.99 *$ & 0.05 & $4.38(0.69)$ & $4.54(0.60)$ \\
\hline $\begin{array}{l}\text { Profesija se uglavnom osla- } \\
\text { nja na intelektualne vještine } \\
\text { i tehnike kako bi se pružila } \\
\text { odgovarajuća usluga. }\end{array}$ & -1.18 & 0.24 & $4.01(0.78)$ & $4.13(0.83)$ \\
\hline $\begin{array}{l}\text { Profesija podrazumijeva } \\
\text { dugi period specijalizirane } \\
\text { izobrazbe. }\end{array}$ & -1.04 & 0.30 & $4.45(0.66)$ & $4.54(0.64)$ \\
\hline $\begin{array}{l}\text { Individualni pripadnici profe- } \\
\text { sije te profesija kao skupina } \\
\text { posjeduju značajan stupanj } \\
\text { autonomije i moći odlučiva- } \\
\text { nja. }\end{array}$ & -0.39 & 0.70 & $4.02(0.79)$ & $4.07(0.84)$ \\
\hline $\begin{array}{l}\text { Profesija obvezuje svoje pri- } \\
\text { padnike da prihvate osobnu } \\
\text { odgovornost za svoja djela } \\
\text { i odluke i općenito svoju } \\
\text { izvedbu. }\end{array}$ & $-3.47 * *$ & 0.01 & $4.45(0.64)$ & $4.71(0.52)$ \\
\hline $\begin{array}{l}\text { Profesija više stavlja nagla- } \\
\text { sak na usluge koje pružaju } \\
\text { njezini pripadnici nego na } \\
\text { njihove financijske nagrade. }\end{array}$ & -1.45 & 0.15 & $4.21(0.85)$ & $4.37(0.87)$ \\
\hline
\end{tabular}




\begin{tabular}{|l|l|l|l|l|}
\hline $\begin{array}{l}\text { Profesija je samoreguliraju- } \\
\text { ća; odgovorna je za uređe- } \\
\text { nje unutarnje strukture i za } \\
\text { postavljanje standarda za } \\
\text { primanje i isključivanje iz } \\
\text { profesije. }\end{array}$ & -0.86 & 0.39 & $3.81(1.01)$ & $3.92(0.95)$ \\
\hline $\begin{array}{l}\text { Profesija ima kodeks ponaša- } \\
\text { nja koji postavlja prihvatljive } \\
\text { standarde ponašanja za svoje } \\
\text { pripadnike profesije. }\end{array}$ & -0.10 & 0.92 & $4.44(0.72)$ & $4.45(0.69)$ \\
\hline $\begin{array}{l}\text { Pripadnici profesije posjedu- } \\
\text { ju suvremeno znanje vezano } \\
\text { za specifično područje. }\end{array}$ & -1.19 & 0.24 & $4.17(0.76)$ & $4.29(0.81)$ \\
\hline $\begin{array}{l}\text { Svi pripadnici profesije imaju } \\
\text { odgovornost uključiti se u ak- } \\
\text { tivnosti svoje profesionalne } \\
\text { organizacije. }\end{array}$ & -0.19 & 0.85 & $4.36(0.71)$ & $4.38(0.77)$ \\
\hline
\end{tabular}

Legenda: t-test - vrijednost t-testa pri testiranju razlike između dviju nezavisnih skupina; ** - značajno uz $5 \%$ rizika $(\mathrm{p}<0.05)$; * - značajno uz $1 \%$ rizika $(\mathrm{p}<0.01) ; \mathrm{p}$ - vjerojatnost pogreške; $\mathrm{M}$ - aritmetička sredina; sd - standardna devijacija; df - stupnjevi slobode

Rezultati u gornjoj tablici donose informacije da postoje dvije statistički značajne razlike u mišljenjima budućih učitelja primarnog obrazovanja o obilježjima profesije s obzirom na trenutačnu godinu studija i to u tvrdnjama: »Profesija pruža jedinstvenu, određenu i esencijalnu uslugu koju mogu pružiti jedino osobe s potrebnom kvalifikacijom za određenu profesiju« $(\mathrm{t}=-1.99 ; \mathrm{df}=242 ; \mathrm{p}<0.05)$ i »Profesija obvezuje svoje pripadnike da prihvate osobnu odgovornost za svoja djela i odluke i općenito svoju izvedbu « $(\mathrm{t}=-3.47 ; \mathrm{df}=230.71 ; \mathrm{p}<0.01)$. Obje razlike idu u istom smjeru i pregledom aritmetičkih sredina možemo uočiti da oni s prve godine imaju niži prosječni rezultat na prvoj $(\mathrm{M}=4.38$; $\mathrm{sd}=0.69)$ kao i na drugoj tvrdnji $(\mathrm{M}=4.45 ; \mathrm{sd}=0.64) \mathrm{u}$ odnosu na one $\mathrm{s}$ pete godine studija $(\mathrm{M}=4.54$; $\mathrm{sd}=0.60$ i $\mathrm{M}=4.71$; $\mathrm{sd}=0.52)$.

Što se tiče drugog zadatka istraživanja, odnosno provjere postoji li statistički značajna razlika u mišljenjima budućih učitelja primarnog obrazovanja o obilježjima profesije s obzirom na vrstu prethodno za- 
vršene srednje škole, ponovno je proveden t-test za nezavisne uzorke (Tablica 3).

Tablica 3. Rezultati t-testa pri testiranju razlike u mišljenjima budućih učitelja primarnog obrazovanja o obilježjima profesije s obzirom na vrstu prethodno završene srednje škole $(\mathrm{df}=241)$

\begin{tabular}{|c|c|c|c|c|}
\hline Zavisne varijable & t-test & $\mathbf{p}$ & $\begin{array}{l}\text { M(sd) } \\
\text { gimn. }\end{array}$ & $\begin{array}{l}\text { M(sd) } \\
\text { struk. }\end{array}$ \\
\hline $\begin{array}{l}\text { Profesija pruža jedinstve- } \\
\text { nu, određenu i esencijalnu } \\
\text { uslugu koju mogu pružiti } \\
\text { jedino osobe s potrebnom } \\
\text { kvalifikacijom za određenu } \\
\text { profesiju. }\end{array}$ & 1.17 & 0.25 & $4.48(0.66)$ & $4.36(0.61)$ \\
\hline $\begin{array}{l}\text { Profesija se uglavnom osla- } \\
\text { nja na intelektualne vještine } \\
\text { i tehnike kako bi se pružila } \\
\text { odgovarajuća usluga. }\end{array}$ & $2.05^{*}$ & 0.04 & $4.12(0.82)$ & $3.85(0.72)$ \\
\hline $\begin{array}{l}\text { Profesija podrazumijeva } \\
\text { dugi period specijalizirane } \\
\text { izobrazbe. }\end{array}$ & -1.11 & 0.33 & $4.47(0.68)$ & $4.57(0.54)$ \\
\hline $\begin{array}{l}\text { Individualni pripadnici } \\
\text { profesije te profesija kao } \\
\text { skupina posjeduju značajan } \\
\text { stupanj autonomije i moći } \\
\text { odlučivanja. }\end{array}$ & 0.99 & 0.32 & $4.07(0.79)$ & $3.94(0.89)$ \\
\hline $\begin{array}{l}\text { Profesija obvezuje svoje pri- } \\
\text { padnike da prihvate osobnu } \\
\text { odgovornost za svoja djela } \\
\text { i odluke i općenito svoju } \\
\text { izvedbu. }\end{array}$ & -0.52 & 0.60 & $4.57(0.60)$ & $4.62(0.61)$ \\
\hline $\begin{array}{l}\text { Profesija više stavlja nagla- } \\
\text { sak na usluge koje pružaju } \\
\text { njezini pripadnici nego na } \\
\text { njihove financijske nagrade. }\end{array}$ & 0.85 & 0.39 & $4.31(0.84)$ & $4.19(0.97)$ \\
\hline
\end{tabular}




\begin{tabular}{|l|l|l|l|l|}
\hline $\begin{array}{l}\text { Profesija je samoreguliraju- } \\
\text { ća; odgovorna je za uređenje } \\
\text { unutarnje strukture i za } \\
\text { postavljanje standarda za } \\
\text { primanje i isključivanje iz } \\
\text { profesije. }\end{array}$ & 0.92 & 0.36 & $3.89(0.97)$ & $3.74(1.03)$ \\
\hline $\begin{array}{l}\text { Profesija ima kodeks pona- } \\
\text { šanja koji postavlja prihvat- } \\
\text { ljive standarde ponašanja za } \\
\text { svoje pripadnike profesije. }\end{array}$ & 0.39 & 0.70 & $4.45(0.68)$ & $4.40(0.80)$ \\
\hline $\begin{array}{l}\text { Pripadnici profesije posjedu- } \\
\text { ju suvremeno znanje vezano } \\
\text { za specifično područje. }\end{array}$ & -0.45 & 0.65 & $4.22(0.82)$ & $4.28(0.65)$ \\
\hline $\begin{array}{l}\text { Svi pripadnici profesije ima- } \\
\text { ju odgovornost uključiti se u } \\
\text { aktivnosti svoje profesional- } \\
\text { ne organizacije. }\end{array}$ & 0.09 & 0.93 & $4.37(0.74)$ & $4.36(0.74)$ \\
\hline
\end{tabular}

Legenda: t-test - vrijednost t-testa pri testiranju razlike između dviju nezavisnih skupina; ** - značajno uz $5 \%$ rizika $(\mathrm{p}<0.05)$; * - značajno uz $1 \%$ rizika $(\mathrm{p}<0.01) ; \mathrm{p}$ - vjerojatnost pogreške; $\mathrm{M}$ - aritmetička sredina; sd - standardna devijacija; df - stupnjevi slobode

Rezultati u gornjoj tablici pokazuju da postoji jedna statistički značajna razlika u mišljenjima budućih učitelja primarnog obrazovanja o obilježjima profesije s obzirom na vrstu prethodno završene srednje škole i to kod tvrdnje: »Profesija se uglavnom oslanja na intelektualne vještine i tehnike kako bi se pružila odgovarajuća usluga « $(\mathrm{t}=2.05$; $\mathrm{df}=242 ; \mathrm{p}<0.05)$. Razlika ide u smjeru da studenti koji su završili gimnaziju postižu viši rezultat na ovoj tvrdnji $(\mathrm{M}=4.12$; sd=0.82) u odnosu na one koji su završili strukovnu školu $(\mathrm{M}=3.85 ; \mathrm{sd}=0.72)$.

Odgovarajući na treći zadatak istraživanja, odnosno pri provjeri postoji li statistički značajna razlika u mišljenjima budućih učitelja primarnog obrazovanja o obilježjima profesije s obzirom na smjer, rezultati t-testa su prikazani u Tablici 4. 
Tablica 4. Rezultati t-testa pri testiranju razlike u mišljenjima budućih učitelja primarnog obrazovanja o obilježjima profesije s obzirom na smjer $(\mathrm{df}=242)$

\begin{tabular}{|c|c|c|c|c|}
\hline Zavisne varijable & t-test & $\mathbf{p}$ & M(sd) 835 & M(sd) 903 \\
\hline $\begin{array}{l}\text { Profesija pruža jedinstvenu, } \\
\text { određenu i esencijalnu uslugu } \\
\text { koju mogu pružiti jedino osobe } \\
\text { s potrebnom kvalifikacijom za } \\
\text { određenu profesiju. }\end{array}$ & -1.43 & 0.13 & $4.38(0.72)$ & $4.51(0.61)$ \\
\hline $\begin{array}{l}\text { Profesija se uglavnom oslanja } \\
\text { na intelektualne vještine i teh- } \\
\text { nike kako bi se pružila odgova- } \\
\text { rajuća usluga. }\end{array}$ & -0.18 & 0.86 & $4.06(0.72)$ & $4.08(0.85)$ \\
\hline $\begin{array}{l}\text { Profesija podrazumijeva dugi } \\
\text { period specijalizirane izobrazbe. }\end{array}$ & 0.31 & 0.75 & $4.51(0.61)$ & $4.48(0.68)$ \\
\hline $\begin{array}{l}\text { Individualni pripadnici profe- } \\
\text { sije te profesija kao skupina } \\
\text { posjeduju značajan stupanj } \\
\text { autonomije i moći odlučivanja. }\end{array}$ & -0.15 & 0.88 & $4.03(0.83)$ & $4.05(0.81)$ \\
\hline $\begin{array}{l}\text { Profesija obvezuje svoje } \\
\text { pripadnike da prihvate osobnu } \\
\text { odgovornost za svoja djela i od- } \\
\text { luke i općenito svoju izvedbu. }\end{array}$ & $-1.95^{*}$ & 0.04 & $4.47(0.68)$ & $4.64(0.54)$ \\
\hline $\begin{array}{l}\text { Profesija više stavlja naglasak } \\
\text { na usluge koje pružaju njezini } \\
\text { pripadnici nego na njihove } \\
\text { financijske nagrade. }\end{array}$ & 1.56 & 0.12 & $4.40(0.72)$ & $4.22(0.92)$ \\
\hline $\begin{array}{l}\text { Profesija je samoregulirajuća; } \\
\text { odgovorna je za uređenje unu- } \\
\text { tarnje strukture i za postav- } \\
\text { ljanje standarda za primanje i } \\
\text { isključivanje iz profesije. }\end{array}$ & 0.64 & 0.52 & $3.92(0.91)$ & $3.83(1.03)$ \\
\hline $\begin{array}{l}\text { Profesija ima kodeks ponaša- } \\
\text { nja koji postavlja prihvatljive } \\
\text { standarde ponašanja za svoje } \\
\text { pripadnike profesije. }\end{array}$ & 1.81 & 0.07 & $4.55(0.61)$ & $4.38(0.75)$ \\
\hline
\end{tabular}




\begin{tabular}{|l|l|l|l|l|}
\hline $\begin{array}{l}\text { Pripadnici profesije posjeduju } \\
\text { suvremeno znanje vezano za } \\
\text { specifično područje. }\end{array}$ & 0.11 & 0.91 & $4.24(0.75)$ & $4.23(0.81)$ \\
\hline $\begin{array}{l}\text { Svi pripadnici profesije imaju } \\
\text { odgovornost uključiti se u } \\
\text { aktivnosti svoje profesionalne } \\
\text { organizacije. }\end{array}$ & -0.62 & 0.53 & $4.33(0.76)$ & $4.39(0.73)$ \\
\hline
\end{tabular}

Legenda: t-test - vrijednost t-testa pri testiranju razlike između dviju nezavisnih skupina; ** - značajno uz $5 \%$ rizika $(\mathrm{p}<0.05)$; * značajno uz $1 \%$ rizika $(\mathrm{p}<0.01) ; \mathrm{p}$ - vjerojatnost pogreške; $\mathrm{M}$ - aritmetička sredina; sd - standardna devijacija; df - stupnjevi slobode

Rezultati u gornjoj tablici donose informacije da postoji jedna statistički značajna razlika u mišljenjima budućih učitelja primarnog obrazovanja o obilježjima profesije s obzirom na smjer i to kod tvrdnje: »Profesija obvezuje svoje pripadnike da prihvate osobnu odgovornost za svoja djela i odluke i općenito svoju izvedbu « $(\mathrm{t}=-1.95$; $\mathrm{df}=242$; $\mathrm{p}<0.05$ ). Razlika idu u smjeru da studenti koji su na smjeru 835 (Engleski jezik, Njemački jezik) postižu niži rezultat na ovoj tvrdnji ( $M=4.47$; $\mathrm{sd}=0.68)$ u odnosu na one koji su na smjeru 903 (Moduli) $(\mathrm{M}=4.63$; $\mathrm{sd}=0.54)$.

\section{Rasprava}

Cilj ovog istraživanja bio je utvrditi mišljenje budućih učitelja primarnog obrazovanja o obilježjima profesije. Potvrđena je prva hipoteza istraživanja koja se odnosi na postojanje statistički značajne razlike u mišljenjima budućih učitelja primarnog obrazovanja s obzirom na trenutačnu godinu studija. Utvrđeno je da se studenti pete godine više slažu s tvrdnjama »Profesija pruža jedinstvenu, određenu i esencijalnu uslugu koju mogu pružiti jedino osobe s potrebnom kvalifikacijom za određenu profesiju « $\mathrm{i}$ »Profesija obvezuje svoje pripadnike da prihvate osobnu odgovornost za svoja djela i odluke i općenito svoju izvedbu« u odnosu na studente prve godine. Time je djelomično potvrđena hipoteza 1 jer se statistički značajne razlike pronalaze u dvije od ukupno deset postavljenih tvrdnji. Razlika bi se mogla objasniti činjenicom da su tijekom petogodišnjeg studija studenti izloženi kolegijima čiji se sa- 
držaj izravno odnosi na (učiteljsku) profesiju, osobito tijekom četvrte i pete godine studija, stoga su na posljednjoj godini studija više upoznati s elementima profesije $\mathrm{u}$ odnosu na studente prve godine studija.

Potvrđena je i druga hipoteza koja se odnosi na postojanje statistički značajne razlike u mišljenjima budućih učitelja primarnog obrazovanja s obzirom na vrstu prethodno završene srednje škole. Utvrđeno je da se studenti koji su prethodno završili srednju školu gimnazijskog usmjerenja više slažu s tvrdnjom »Profesija se uglavnom oslanja na intelektualne vještine i tehnike kako bi se pružila odgovarajuća usluga « u odnosu na studente koji su prethodno završili srednju školu strukovnog usmjerenja. Time je djelomično potvrđena hipoteza 2 jer se statistički značajna razlika pronalazi u jednoj od deset postavljenih tvrdnji. Razlika bi se mogla objasniti razlikom između programa gimnazijskog usmjerenja i programa strukovnog usmjerenja. Dok su gimnazijski programi uglavnom usmjereni na intelektualne vještine, u strukovnim programima su zastupljene praktične vještine koje se izvode za vrijeme strukovno-specifičnih predmeta kao i za vrijeme izvođenja vježbi na potencijalnom budućem radnom mjestu.

Treća hipoteza koja se odnosi na postojanje statistički značajne razlike u mišljenjima budućih učitelja primarnog obrazovanja s obzirom na smjer pohađanja (903 ili 835) također je potvrđena. Utvrđeno je da se studenti koji pohađaju smjer 835 (Engleski jezik, Njemački jezik) manje slažu s tvrdnjom »Profesija obvezuje svoje pripadnike da prihvate osobnu odgovornost za svoja djela i odluke i općenito svoju izvedbu « u odnosu na studente koji pohađaju smjer 903 (Moduli). Time je djelomično odbačena nul hipoteza 3 jer se statistički značajna razlika pronalazi u samo jednoj od ukupno deset postavljenih tvrdnji.

Budući da rezultati istraživanja pokazuju da sve postavljene tvrdnje o obilježjima profesije imaju vrijednost aritmetičke sredine 3.9 ili više, što ih svrstava u kategorije slaganja i potpunog slaganja, može se zaključiti da je kod studenata razvijena osjetljivost za prepoznavanje obilježja profesije. Do djelomično istih rezultata dolazi i Cobbold $(2015,132)$ u svom istraživanju prema kojem ispitanici, studenti diplomskog učiteljskog studija, smatraju da profesija: podrazumijeva dug period specijalizirane izobrazbe, obvezuje svoje pripadnike da prihvate osobnu odgovornost za svoja djela i odluke i općenito svoju izvedbu te da pretpostavlja kodeks ponašanja koji postavlja prihvatljive standarde 
ponašanja za svoje pripadnike. Zanimljivo je istaknuti da se ispitanici tog istog istraživanja ne slažu s tvrdnjama da pripadnici profesije posjeduju značajan stupanj autonomije i moći, da je profesija samoregulirajuća te da više stavlja naglasak na usluge koje pružaju njezini pripadnici nego na financijske nagrade. Do djelomično sličnih rezultata u svom istraživanju dolaze i Hargreaves et al. (2007, 33-34) prema kojem ispitanici smatraju da profesiju visokog statusa definira poštovanje klijenata i vlade, autonomija individualnih pripadnika profesije u donošenju odluka koje su najbolje za njihovog klijenta te autoritet $u$ području struke.

Ograničenja ovog istraživanja odnose se prvenstveno na uzorak jer je istraživanje provedeno samo na studentima Učiteljskog fakulteta Sveučilišta u Zagrebu. Rezultati bi možda bili od veće značajnosti da se istraživanje provede na većem uzorku studenata različitih fakulteta $u$ Republici Hrvatskoj.

\section{Zaključak}

Da bi se shvatila kompleksnost i opseg posla koju podrazumijeva određena profesija, potrebno je definirati njezine elemente. Predstavljene definicije profesije u ovom radu, iako djelomično različite, imaju iste određene elemente poput: monopol nad znanjem i vještinama iz specifičnih područja, kontinuirani profesionalni razvoj i usavršavanje te autonomiju u donošenju odluka. Ovim radom utvrđeno je da se i mišljenja budućih učitelja primarnog obrazovanja podudaraju s elementima profesije koje pronalazimo u predstavljenim definicijama. Budući da rezultati ovog istraživanja pokazuju da se budući učitelji primarnog obrazovanja slažu ili u potpunosti slažu sa svih deset predstavljenih tvrdnji o obilježjima profesije, predlažu se istraživanja studentskih mišljenja o obilježjima učiteljske profesije. Bilo bi zanimljivo utvrditi do koje razine učitelji primarnog obrazovanja učiteljstvo prepoznaju kao profesiju i jesu li ispunjeni svi uvjeti da bi se učiteljstvo moglo nazvati profesijom. Daljnjim istraživanjima bilo bi potrebno utvrditi koji su elementi specifični za učiteljsku profesiju, kao i to što podrazumijeva učiteljski posao u 21. digitaliziranom stoljeću. 


\section{Literatura}

Anić, Vladimir i Goldstein, Ivo (2005), Rječnik stranih riječi, Zagreb: Novi Liber.

Bergmark, Ulrika; Lundström, Stefan; Manderstedt, Lena i Palo, Annbritt (2018), »Why become a teacher? Student teachers' perception of the teaching profession and motives for career choice«, European Journal of Teacher Education, 41(3), str. 266-281. https://doi.org/10.1080/02619768.2018.1448784

Cobbold, Cosmas (2015), »Professionals without a profession? The paradox of contradiction about teaching as a profession in Ghana", Journal of Education and Practice, 6(6), str. 125-134. Dostupno na: https://files.eric.ed.gov/fulltext/EJ1083583.pdf [4. 10. 2021.]

Demir, Servet (2016), »An analysis of pre-service teachers' attitudes and opinions regarding the teaching profession via Q-methodology«, European Journal of Contemporary Education, 17(3), str. 295-310. https://doi.org/10.13187/ ejced.2016.17.295

Department of Education and Skills (2001), »Schools achieving success«, gov.uk. Dostupno na: https://assets.publishing.service.gov.uk/government/uploads/ system/uploads/attachment_data/file/355105/Schools_Achieving_Success. pdf [4. 10. 2021.]

Domović, Vlatka (2011), »Učiteljska profesija i profesionalni identitet učitelja«, u: Vizek Vidović, Vlasta (ur.), Učitelji i njihovi mentori, Zagreb: Institut za društvena istraživanja, str. 11-37.

Domović, Vlatka i Vizek Vidović, Vlasta (2013), »Uvjerenja studentica učiteljskog fakulteta o ulozi učitelja, učenika i poučavanju«, Sociologija i prostor: časopis za istraživanje prostornog i sociokulturnog razvoja, 51(3), str. 493-508. https://doi.org/10.5673/sip.51.3.3

Fokkens-Bruinsma, Marjon i Canrinus, Esther Tamara (2014), »Motivation for becoming a teacher and engagement with the profession: Evidence form different contexts «, International Journal of Educational Research, 65, str. 65-74. https://doi.org/10.1016/j.ijer.2013.09.012

Hargreaves, Linda; Cunningham, Mark; Hansen, Anders; McIintyre, Donald i Oliver, Caroline (2007), »The status of teachers and the teaching profession in England: Views from inside and outside the profession«, educ.cam.ac.uk. Dostupno na: educ.cam.ac.uk/research/programmes/teacherstatus/Summaryreport_25Jan07_print_ready_version.pdf

Hotaman, Davut (2010), »The teaching profession: Knowledge of subject matter, teaching skills and personality traits «, Procedia Social and Behavioral Sciences, 2(2), str. 1416-1420. https://doi.org/10.1016/j.sbspro.2010.03.211

Ingersoll, Richard M. i Perda, David (2008), »The status of teaching as a profession«, u: Ballantine, Jeanne i Spade, Joan (ur.), Schools and Society: A Sociological Approach to Education, Los Angeles: Pine Forge Press, str. 106-118.

Klaić, Bratoljub (2001), Rječnik stranih riječi, Zagreb: Nakladni zavod Matice hrvatske. 
Kline, Rex B. (2010), Principles and Practice of Structural Equation Modeling, New York: Guilford Press.

Markočić Dekanić, Ana; Markuš Sandrić, Marina i Gregurović, Margareta (2019), TALIS 2018: Učitelji, ravnatelji i nastavnici - cjeloživotni učenici, Zagreb: NCVVO.

Mejovšek, Milko (2008), Metode znanstvenog istraživanja u društvenim i humanističkim znanostima, Zagreb: Naklada Slap.

Musa, Anamarija i Džinić, Jasmina (2012), Europska regulacija profesija i komore u Hrvatskoj: razvoj upravne profesije i drugih profesija u javnoj upravi, Zagreb: Institut za javnu upravu.

[NN] Narodne novine (2008), Zakon o odgoju i obrazovanju u osnovnoj i srednjoj školi, 87/2008 [25. 7. 2008.]

[NN] Narodne novine (2009), Zakon o reguliranim profesijama i priznavanju inozemnih stručnih kvalifikacija, 82/2015 [24. 7. 2015.]

OECD (2016b), »Supporting Teacher Professionalism: Insights from TALIS 2013“, oecd.org. Dostupno na: https://read.oecd-ilibrary.org/education/supporting-teacher-professionalism_9789264248601-en [4. 10. 2021.]

Petričević, Dušan (2011), »Prilog raspravi o profesiji: Andragog«, Andragoški glasnik, 15(1), str. 11-28.

Runte, Robert (1995), »Is teaching a profession?«, u: Taylor, Gerald i Runte, Robert (ur.), Thinking About Teaching: An Introduction, Canada: Harcourt Brace.

Saks, Mike (2012), »Defining a profession: The role of knowledge and expertise, professions \& professionalism«, Professions and Professionalism, 2(1), str. 1-10. https://doi.org/10.7577/pp.v2i1.151

Šporer, Željka (1990), Sociologija profesija: Ogled o društvenoj uvjetovanosti profesionalizacije, Zagreb: Sociološko društvo Hrvatske.

Turner, C. i Hodge, M. N. (1970), »Occupations and Professions«, u: Jackson, John Archer (ur.), Profession and Professionalization, London: Cambridge University Press, str. 17-50.

Učiteljski fakultet Sveučilišta u Zagrebu (2019), »Red predavanja Učiteljskog fakulteta za akademsku godinu 2019./2020.«, ufzg.unizg.hr. Dostupno na: https://www.ufzg.unizg.hr/wp-content/uploads/2020/01/RED-PREDAVANJA-UC\%CC\%8CITELJSKOG-FAKULTETA-ZA-AKADEMSKU-GODINU-2019.-2020.pdf

Victoria, Artur (2018), »Characteristics of a Profession«. https://doi.org/10.13140/ RG.2.2.36676.32643 


\section{OPINIONS OF FUTURE PRIMARY EDUCATION TEACHERS ON THE CHARACTERISTICS OF THE PROFESSION}

\section{Petra Kuntin}

In this paper, the opinion of students of primary education regarding the characteristics of a profession will be determined. The aim of this research is to establish opinion of students of primary education regarding characteristics of a profession. Independent variables are current year of study, previously finished high school and module/course students take. The research was conducted with a questionnaire in the academic year 2019/2020. The sample consisted of students of the first and fifth year at the Faculty of Teacher Education, University of Zagreb. The results show that students of primary education recognize characteristics of a profession. There is a statistically significant difference between students of different years of study and with different previous education.

Keywords: primary education, profession, students, teacher 